\title{
INFLUENCE OF TEMPREATURE -HUMIDITY INDEX LEVEL ON OVARIAN ACTIVITY AND CONCEPTION RATE IN EGYPTAIN BALADI COWS UNDER CLIMATIC CONDITIONS OF ASWAN GOVERNORATE
}

A. I. Damarany

Department of Animal and Poultry Production, Faculty of Agriculture and Natural Resources, Aswan University, Egypt

Received: 18/9/2019

Accepted: 12/11/2019

\section{SUMMARY}

The present investigation aimed to study the effects of temperature-humidity index (THI) level, on the ovarian activity and conception rate of Egyptian Baladi cows. A total number of 40 Baladi cows was used in this study. The cows were divided into three groups according to time of calving. The first group (15 cows) calved during (December, January and February) where THI (68.1- 70.5) was considered as (non-heat stress), the second group calved during (November, March and April) THI (74.5-76.9) (mild-heat stress=10 cows) and the third group calved during (May to October) THI (80.1- 83.9) (moderate-heat stress $=15$ cows). The results demonstrated that the percentage of cows that resumed ovarian activity post-partum were significantly $(P<0.05)$ higher $73.3 \%$ in the first group compared to 50 and $33.3 \%$ in the second and third groups, respectively. Incidence, of quiet ovulation was higher (20\%) in the second and third groups compared to first group $(18.2 \%)$. The percentage of anestrous cases was significantly $(P<0.05)$ higher $(50,66.7 \%)$ in the second and third group compared with the first group (36.4\%). Conception rate was significantly $(P<0.05)$ higher $(77.8 \%)$ in the first group compared to third group $(50 \%)$. The intensity of estrus symptoms was significantly $(P<0.05)$ higher in the first group compared to the second and third groups. In conclusion, the present results illustrated the detrimental effect of increased temperature-humidity index level (THI) on ovarian activity and conception rate of Egyptian Baladi cows. This study recommends the stockholders of cows in Aswan governorate to arrange the cows calvings during the cold months or use some procedures such as sprinkling by water and fan in order to reduce the hurtful effects of higher THI level on fertility in Egyptian Baladi cows.

Keywords: Temperature-humidity index, ovarian activity, conception rate, Egyptian Baladi cows

\section{INTRODUCTION}

Global warming is considered one of the vital issues at the last decade in the world. The heat stress had harmful effects on the livestock and influences all internal physiological activities in the body. Many researches recorded negative relationship between increasing the heat stress and impairment of the reproductive performance in cows. Sartori et al. (2002), De Rensis et al. (2002) and Sonmez et al. (2005) reported that increased environmental temperature and relative humidity affect the endocrine activity and decreases the reproductive performance in cows. Souza et al. (2007) recorded that luteinizing hormone (LH) secretion during preovulation period decline by half amount in lactating dairy cows when exposed to heat stress. In addition, Ju (2005) and Hansen (2009) suggested that heat stress lead to impair oocyte growth and maturation. Khodaei-Motlagh et al. (2011) found that small size of ovulatory follicle/s and low luteinizing hormone (LH) secretion from the anterior pituitary gland in dairy cattle occur in heat stress. Soto and Smith (2009) and Zhandi et al. (2009) reported that heat stress activate apoptosis in bovine oocytes. De Rensis and Scaramuzzi (2003) suggested that heat stress in summer lead to increased occurrence of silent ovulation and reduced signs of estrus. Wolfenson et al. (1997) and Roth et al. (2001) found that increased environment temperature affects endocrine activity and impair the estrus expression. Singh et al. (2013) suggested that lower concentration of oestradiol during summer season, which causes impair intensity of estrus signs and increase silent heat in buffaloes. Collier et al. (2006) found that heat stress had a negative effect on manifestation of estrus behavior of dairy cattle. Kumar et al. (2014) suggested that environmental stress and inadequate nutrition are considered from important factors that affects the appearance anestrous cases in cows. De Rensis and Scaramuzzi (2003) found that percentage of anoestrus cases was higher in dairy cow during the heat stress in summer. Schüller et al. (2014) reported that conception rate was reduced from $(30.4 \%$ to $14.4 \%$ ) when temperature humidity index (THI) increased from (55 to 76) in dairy cows. GarciaIspierto et al. (2007) and Morton et al. (2007) observed similar trend, since they reported that the cows exposed to heat stress before mating demonstrated lower conception rate. Astiz and Fargas (2013) recorded that conception rate was lower in primiparous and multiparous cow during the hot season compared to cold season. Schüller et al. (2017) found lower conception rate in dairy cows when exposed to at the temperature humidity index (THI) above 72 at the day of estrus. Ferreira et al. (2011) and Gendelman and Roth (2012) reported that exposing the cows to heat stress lead to impair oocyte quality. Gendelman et al. (2010) and Silva et al. (2013) found lower embryo development in dairy cow under heat stress conditions. Furthermore, 
Amundson et al. (2006) observed negative correlation between temperature humidity index (THI) and pregnancy rate of crossbred cows. Aswan governorate is area which has higher ambient temperature during the hot season reaching more than $\left(40^{\circ} \mathrm{C}\right)$ compared to other locations in Egypt. Little information about the effect of heat stress on the reproductive activity of Baladi cattle is available. The present investigation aim to, investigate the influence of temperature-humidity index level, on the ovarian activity and conception rate of Egyptian Baladi cattle under the climatic conditions of Aswan governorate.

\section{MATERIALS AND METHODS}

Farm location and climatic conditions:

The investigation was carried out in an animal farm located in Kom Ombou area (32, 31' 23" East and 22, 28' 09" North), Aswan governorate. The cattle were kept in traditional farm under semishaded system. The climate of Aswan is higher ambient temperature and lower relative humidity especially during the hot season. Table (1) clarifies the average of the ambient temperature, relative humidity and temperature humidity index during the experimental period. Temperature humidity index (THI) was calculated according to the formula proposed by Mader et al. (2006):

$\mathrm{THI}=(0.8 \times \mathrm{Tmax} \mathrm{db})+[(\mathrm{RH} / 100) \times(\mathrm{T} \max \mathrm{db}$ $-14.4)]+46.4$

Temperature-humidity index $(\mathrm{THI})=0.8 \mathrm{x}$ ambient temperature $+[(\%$ relative humidity) 100$) \times$ (ambient temperature -14.4$)]+46.4$

Table 1. The ambient temperature $\left({ }^{\circ} \mathrm{C}\right)$, relative humidity $(\mathrm{RH} \%)$ and temperature humidity index (THI) during the experimental period

\begin{tabular}{lcccc}
\hline \multirow{2}{*}{ Months of calving } & \multicolumn{2}{c}{$\begin{array}{c}\text { Average } \\
\text { Ambient Temperature }\left({ }^{\mathbf{0}} \mathbf{C}\right)\end{array}$} & $\begin{array}{c}\text { Average } \\
\text { Relative humidity (RH \%) }\end{array}$ & THI \\
\cline { 2 - 3 } January & Min. & Max. & & 64.9 \\
February & 13.2 & 21.2 & 22 & 68.1 \\
March & 15.9 & 24.2 & 23 & 75.8 \\
April & 18.3 & 32.2 & 20 & 76.9 \\
May & 20.1 & 34.0 & 17 & 83.2 \\
June & 22.6 & 40.7 & 16 & 83.8 \\
July & 25.3 & 41.4 & 16 & 83.9 \\
August & 26.2 & 41.2 & 17 & 83.9 \\
September & 26.0 & 41.0 & 18 & 81.9 \\
October & 23.8 & 38.4 & 20 & 80.1 \\
November & 23.1 & 37.2 & 17 & 74.5 \\
December & 20.4 & 31.3 & 18 & 70.5 \\
\hline
\end{tabular}

\section{Management and feeding of animals:}

A total number of 40 Baladi cattle was used in the present work. Cows parity ranged between $3^{\text {rd }}$ and $5^{\text {th }}$. Body weight and age of cows at calving are presented in table (2).Animals were fed on Egyptian clover (Trifolium alexandrinum) alongside the concentrate ration and wheat hay were offered during December to the end of April. Corn fodder, wheat hay and concentrate ration were used during the period from May to the end of November.

Table 2. Specifications (Mean \pm SE) of cows none, mild and moderate- heat stress

\begin{tabular}{lcc}
\hline Groups & Body weight (kg) & Age (years) \\
\hline None - heat stress & $383.25 \pm 12.23$ & $6.36 \pm 2.42$ \\
Mild-heat stress & $371.72 \pm 13.91$ & $5.98 \pm 2.31$ \\
Moderate- heat stress & $368.32 \pm 11.43$ & $6.43 \pm 3.22$ \\
\hline
\end{tabular}

\section{Experiment design:}

Forty Baladi cows were divided into three groups according to time of calving (non-heat stress $=15$ cows, mild-heat stress $=10$ cows and moderate-heat stress $=15$ cows. The first group calved during (December, January and February), the second group calved during (November, March and April) and the third group calved during (May to October) as shown in table (3). The cows were followed up after oneweek post-partum. Table (4) clarifies the classification of zones based on THI values in cattle with THI model according to (Samal, 2013).

Table 3. Classification months of calving and THI during the experimental period

\begin{tabular}{lccc}
\hline Months of calving & Number & THI Range & Stress level \\
\hline December, January and February & 15 & $(68.1-70.5)$ & None \\
November, March and April & 10 & $(74.5-76.9)$ & Mild \\
May to October & 15 & $(80.1-83.9)$ & Moderate \\
\hline
\end{tabular}


Table 4.Classification of zones based on THI values in cattle with THI model according to (Samal, 2013)

\begin{tabular}{|c|c|c|}
\hline THI & Stress level & Response of cattle \\
\hline$<72$ & Non & Non-noticeable \\
\hline $72-79$ & Mild & $\begin{array}{l}\text { Dairy cows will adjust by seeking shade, increasing respiration rate and dilation of } \\
\text { the blood vessels. The effect on milk production will be minimal. }\end{array}$ \\
\hline $80-89$ & Moderate & $\begin{array}{l}\text { Both saliva production and respiration rate will increase. Feed intake may be } \\
\text { depressed and water consumption will increase. There will be an increase in body } \\
\text { temperature. Milk production and reproduction will be decreased. }\end{array}$ \\
\hline $90-98$ & Severe & $\begin{array}{l}\text { Cows will become very much uncomfortable due to high body temperature, rapid } \\
\text { respiration (panting) and excessive saliva production. Milk production and } \\
\text { reproduction will be markedly decreased. }\end{array}$ \\
\hline$>98$ & Danger & Potential cow deaths can occur. \\
\hline
\end{tabular}

\section{Heat detection and pregnancy diagnosis:}

Heat detection was performed by daily visual observation for cows in the morning at 6:0 am and night and 18:0 pm. Just, any sexual behavior symptoms display, cows were considered in heat. The cows were naturally inseminated once exhibited standing symptoms of heat. Rectal palpation (60 days post-mating) was used to diagnose and establish of pregnancy as described by Arthur (1964).

Conception rate: was calculated as the percentage of cows, which conceived from the first mating postpartum

Conception rate $=$ Number of pregnant cows $/$ Total number of mated cows $x 100$.

\section{Detection ovarian activity:}

The ovarian activity was confirmed by plasma progesterone concentration (once a week sampling), just plasma progesterone concentration rise up to the basal line $(1 \mathrm{ng} / \mathrm{ml})$ blood, hence the ovary started its activity. Alongside, rectal palpation was performed for detection the corpus luteum on the ovary in weekly basis. Figure (1) clarifies metabolic mechanisms that affect reproduction during heat stress in dairy cows. In addition, figure (2) illustrate effects of seasonal heat stress and photoperiod on the endocrine mechanisms that control reproduction in dairy cows proposed by De Rensiset al. (2017).

\begin{tabular}{|c|c|c|}
\hline Metabolic effect of heat stress & Effect on ovarian activity & Clinical consequence \\
\hline $\begin{array}{l}\text { Panting and salivary drooling. } \\
\text { Induced altered acid-basic } \\
\text { balance } \\
\text { Reduced appetite \& feed } \\
\text { intake - negative energy } \\
\text { balance - altered plasma levels } \\
\text { of metabolic hormones } \\
\text { Increased reactive oxygen } \\
\text { species (ROS) }\end{array}$ & $\begin{array}{l}\text { Decreased GnRH } \\
\text { and LH } \\
\text { Compromised } \\
\text { follicular development } \\
\text { and mechanism of } \\
\text { ovulation } \\
\text { Altered insulin, } \\
\text { IGF-I, T3,T } 4 \text { and } \\
\text { glucose }\end{array}$ & $\begin{array}{l}\text { Failure of AI } \\
\text { Poor estrus } \\
\text { expression } \\
\text { Anestrus and } \\
\text { prolonged calving } \\
\text { to conception } \\
\text { interval }\end{array}$ \\
\hline
\end{tabular}

Figure 1. Metabolic mechanisms that effect reproduction during periods of seasonal heat stress in dairy cows (De Rensiset al. (2017).

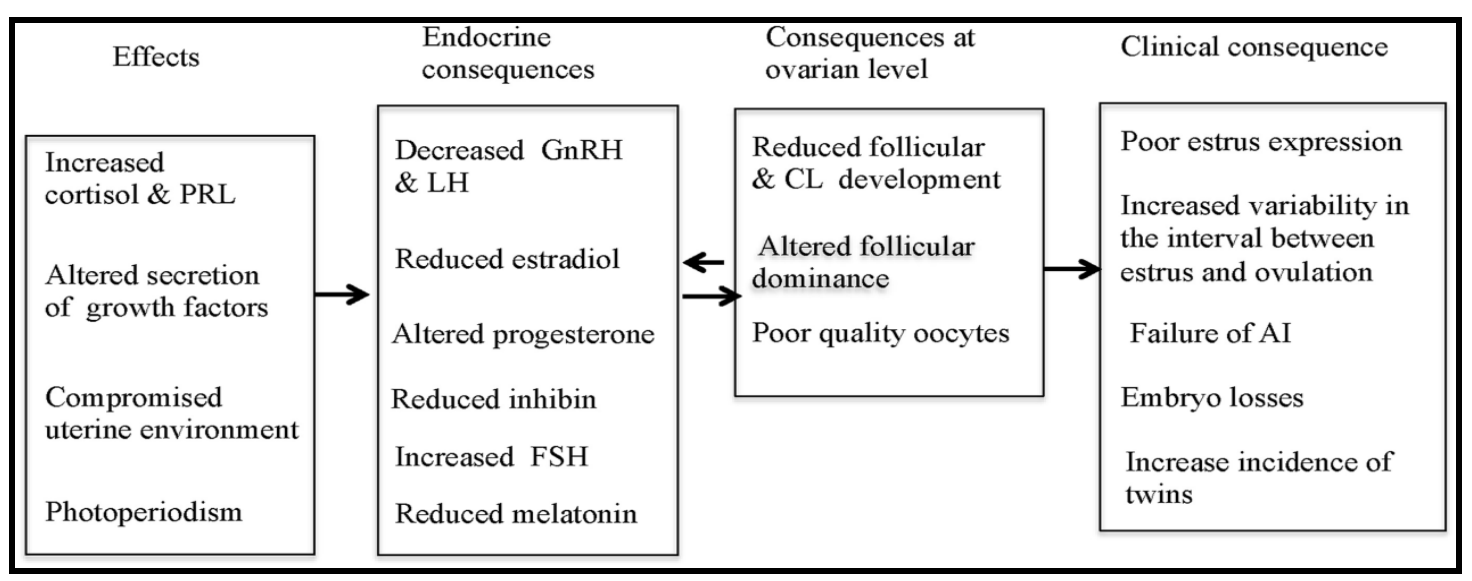

Figure 2. Effects of seasonal heat stress and photoperiod on the endocrine mechanisms that control reproduction in dairy cows (De Rensis et al. 2017). 


\section{Hormones analysis:}

Blood samples $(5 \mathrm{ml})$ were collected at estrus, day 7, 14 and 21 after mating in heparinized tubes from the jugular vein. The blood samples were centrifuged at $3000 \mathrm{rpm}$ for 20 minutes for plasma harvesting. Plasma was separated and stored at $-18^{\circ} \mathrm{C}$ until the time of analysis. Progesterone (P4) hormone was determined using radioimmunoassay kit (Immunotech, France). Sensitivity value reported to be according to manufacturer information. The intraand inter-assay variation coefficients were 5.3 and $12.4 \%$, respectively.

\section{Statistical analysis:}

The statistical design included one factor (effect of temperature-humidity index (THI) on ovarian activity and conception rate), the analysis was performed by using SAS (2002). The following model was used:

$\mathbf{Y}_{\mathrm{ij}}=\boldsymbol{\mu}+\mathbf{T}_{\mathrm{i}}+\mathbf{e}_{\mathrm{ij}}$

Where:

$\mathbf{Y}_{\mathbf{i j}}=$ the observation trait

$\boldsymbol{\mu}=$ overall mean

$\mathbf{T}_{\mathbf{i}}=$ effect of THI (non-heat stress $=1$, mild-heat stress $=2$ and moderate-heat stress $=3$ )

$\mathbf{e}_{\mathbf{i j}}=$ experimental error

Duncan's Multiple Range test (Duncan, 1955) was used to test the significance of the differences between means. Chi Square was performed.

\section{RESULTS AND DISCUSSION}

Effect of temperature humidity index on resumption of ovarian activity of Egyptian Baladi cows:

Table (5) indicates the percentage of cows that resumed ovarian activity were significantly $(P<0.05)$ higher $73.3 \%$ in Baladi cows that calved during the cool months (December, January and February) (nonheat stress) under temperature humidity index (THI) ranging between (68.1 and 70.5) compared with those calved during in the other months. The interval from calving to the first ovulation (considered one of the important indicators of resumption of ovarian activity after calving) was significantly $(P<0.05)$ lower $(50.9 \pm 18.8$ days $)$ in cows that calved during the cool months (non- heat stress) than the cows calved during the interval locate in mild or moderate heat stress table (5). The current result are in agreement with those reported by Sartori et al. (2002) and Sonmez et al. (2005) who found that increased environment temperature and relative humidity affect on endocrine activity and decline reproductive performance of dairy and beef cows. Wise et al. (1988) and Giladet al. (1993) reported that heat stress affect on endocrine activities this lead to decline luteinizing hormone (LH) and follicle stimulating hormone (FSH) in dairy cows. Wolfenson et al. (1995) and Roth et al. (2000) observed that heat stress negatively affects on ovary via inhibiting of follicular growth and reducing quality of oocyte. Hansen et al. (2001) showed significant decline in the number of oocytes and development competence during heat stress conditions in dairy cows. Bearden and Fuquay (1992) suggested that heat stress lead to secretion of ACTH from the anterior pituitary gland, which causes in release of glucocorticoids from the adrenal gland. Glucocorticoids had inhibiting effect on luteinizing hormone (LH) from the pituitary gland Souza et al. (2007) reported decline of luteinizing hormone (LH) secretion during pre-ovulation period by half amount in lactating dairy cows that exposed to heat stress. Wolfenson et al. (2000) reported that heat stress domination on the mechanism of hypothalamus-hypophyseal-ovarian axis in animals, via cause's hyper-prolactinemia, reduction in (LH) secretion and decrease maturation of follicle in ovary. Roy and Prakash (2007) reported that concentration of prolactin in plasma was higher during the summer season than winter season, which maybe associate with a cyclicity or infertility in buffaloes. Alamer (2011) and Singh et al. (2013) suggested that increase of prolactin level in the blood during heat stress was responsible for acyclicity and infertility in buffaloes. Wolfenson et al. (1993) reported that heat stress lead to decrease the number of granulosa cells, aromatase activity and secretion of androstenedione by theca cells. Heat stress caused delay growth and decline function of dominant ovarian follicles Hansen (1994). In another study, for Hansen (2007) suggested that the mechanisms effect of heat stress on oocytes growth by declining synthesis of preovulatory surge of (LH). The previous factors lead to bad follicle maturation and this leads to inactive ovaries in cows. Wilson et al. (1998) reported that decease viability of granulosa cells and/or additional alteration in steriodogenic enzymes may lead to odd ovarian dynamics during the heat stress in dairy cattle. Roth and Hansen (2004), Soto and Smith (2009) and Zhandi et al. (2009) suggested that heat stress activate apoptosis in bovine oocytes. Ju (2005) and Hansen (2009) reported that heat stress lead to impair oocyte growth and maturation. Paula-Lopes and Hansen (2002) found that oocyte exposed to high oxidative damage and apoptotic cell death during the heat stress. Hansen (2009) reported that heat stress impair follicular dominance via motivate multiple large $(>10 \mathrm{~mm})$ follicles beside extended dominance of ovulatory follicles. Mihm et al. (1994) found that extended follicular dominance hold up normal oocyte maturation (eg. premature meiosis) and decline developmental competence. Khodaei-Motlagh et al. (2011) found that small size of ovulatory follicle/s and low luteinizing hormone (LH) secretion from the anterior pituitary gland in dairy cattle occur in heat stress. Curtis et al. (2017) reported that impair in appetite of cattle during heat stress conditions lead to reduce feed intake. Negative energy balance was observed in cattle that exposed to heat stress (Wheelock et al., 2006). Decline of DMI lead to reduce follicular growth by modifyjng LH secretion and/ or impair circulating IGF-I concentrations (Wilson et al., 1998). 
Table 5. Effect of temperature humidity index (THI) on resumption of ovarian activity during 90 days postpartum of Egyptian Baladi cows

\begin{tabular}{lccc}
\hline Items & \multicolumn{3}{c}{ Heat stress level } \\
\cline { 2 - 4 } & None & Mild & Moderate \\
\cline { 2 - 4 } & & THI & \\
& $(\mathbf{6 8 . 1 - 7 0 . 5 )}$ & $\mathbf{( 7 4 . 5 - 7 6 . 9 )}$ & $\mathbf{( 8 0 . 1 - 8 3 . 9 )}$ \\
\hline No. of cases & 15 & 10 & 15 \\
Number of cows resumption of ovarian activity & 11 & 5 & 5 \\
Percentage of cows resumption of ovarian activity (\%) & $73.3^{\mathrm{a}}$ & $50^{\mathrm{b}}$ & $33.3^{\mathrm{c}}$ \\
$1^{\text {st }}$ Ovulation post-partum (days) & $50.9 \pm 18.8^{\mathrm{a}}$ & $71.8 \pm 7.9^{\mathrm{b}}$ & $83.4 \pm 5.1^{\mathrm{c}}$ \\
Quiet ovulation (\%) & $18.2(2)$ & $20(1)$ & $20(1)$ \\
Anestrous cases (\%) & $36.4(4)^{\mathrm{a}}$ & $50(5)^{\mathrm{b}}$ & $66.7(10)^{\mathrm{c}}$ \\
Conception rate (\%) & $77.8(7)^{\mathrm{a}}$ & $75.0(3)^{\mathrm{a}}$ & $50.0(2)^{\mathrm{b}}$ \\
\hline
\end{tabular}

$\mathrm{a}, \mathrm{b}$ and $\mathrm{c}$ : values within the same row having different superscripts are significantly different at $(\mathrm{P}<0.05)$

1-Conception rate from first service

Effect of temperature humidity index on quiet ovulation of Egyptian Baladi cows:

Incidence of quiet ovulation was higher $(20 \%)$ in Baladi cows in mild and moderate heat stress level compared to none heat stress (table 5). The current result corresponds with those reported by Hansen and Aréchiga (1999) and Lucy (2002) who found that higher occurrence of silent ovulation in cows. Lewis et al. (1984), Cavestany et al. (1985) and White et al. (2002) reported that heat stress caused decline intensity and duration of estrus and increases the incidence of quiet ovulation. De Rensis and Scaramuzzi (2003) suggested that heat stress in summer lead to increased occurrence of silent ovulation and reduced signs of estrus. Lee (1993), Wolfenson et al. (1997) and Roth et al. (2001) found that increase environment temperature affects endocrine activity and impair the estrus expression. Singh et al. (2013) suggested that lower concentration of oestradiol during summer season, which causes impair intensity of estrus signs and increase silent heat in buffaloes. Hansen et al. (1992), Hansen (1994) and Wilson et al. (1998) reported that heat stress causes a decline in circulating estradiol concentrations at first wave dominant follicle development and pro-estrus of dairy cows. Lyimo et al. (2000) recorded that there was positive correlation $(r=0.7)$ between estradiol concentration and estrous behavior. Collier et al. (2006) found that heat stress had a negative effect on manifestation of estrus behavior of dairy cattle. Rodtian et al. (1996) and López-Gatius et al. (2008) suggested that ovulations without any estrous symptoms are more frequent during the hot months of the year. Wolfenson et al. (1997) and Roth et al. (2001) reported that the main effect of heat stress on heat detection rates due to decline the steroidogenic capacity of theca and granulosa cells lead to alternating in circulating estradiol concentrations. Britt et al. (1986) and Lopez et al. (2004) recorded that there is a positive association between intensity and duration of estrus and estradiol concentration in the blood.
Effect of temperature humidity index on anestrous cases of Egyptian Baladi cows:

Table (5) indicated that the percentage of anestrous cases was significantly $(P<0.05)$ higher $(50,66.7 \%)$ in Baladi cows that calved during mild (November, March and April) THI (74.5- 76.9) and moderate (May to October) THI (80.1- 83.9) heat stress level, compared with cows that calved during none heat stress level. The present result agrees with that reported by Hansen and Aréchiga (1999) and Lucy (2002) who found that increase frequency of anoestrous cases when cows exposed to heat stress. Kumar et al. (2014) suggested that environmental stress and inadequate nutrition are considered from important factors that affects appearance anestrous cases in cows. De Rensis and Scaramuzzi (2003) found that percentage of anoestrus cases was higher in dairy cow during the heat stress in summer. Lee (1993), Wolfenson et al. (1997) and Roth et al. (2001) recorded that heat stress during the hot season influences the hormonal activity and impairs the estrus expression. Wise et al. (1988) and Gilad et al. (1993) suggested that heat stress influences endocrine activity, which causes decreases of (LH) and (FSH) hormones secretion in dairy cows. Wolfenson et al. (1995) and Roth et al. (2000) showed that heat stress had a negative effect on ovary via inhibition follicular growth. Souza et al. (2007) observed that decreased (LH) secretion during pre-ovulation period by half amount in dairy cows that exposed to heat stress.

\section{Effect of temperature humidity index on conception rate of Egyptian Baladi cows:}

Table (5) indicated that conception rate was significantly $(P<0.05)$ higher $(77.8 \%)$ of Baladi cows that calved during the cool months (December, January and February) (non- heat stress) under temperature humidity index (THI) ranging between (68.1 and 70.5) than other cows that calved throughout (May to October) (THI) ranging between (80.1-83.9). The present result corresponds with that reported by Schüller et al. (2014) who found that conception rate was reduced from (30.4\% to $14.4 \%)$ when temperature humidity index (THI) increased from (55 to 76) in dairy cows. Garcia-Ispierto et al. 
(2007) and Morton et al. (2007) observed similar trend, since they reported that cows exposed to heat stress before mating demonstrated lower conception rate. Astiz and Fargas (2013) suggested that conception rate was lower in primiparous and multiparous cows during the hot season compared to cold season. De Rensis et al. (2002) reported that the metabolic stress leads to a decline in conception rate during the hot months by 20 to $30 \%$ compared with cold months in dairy cows. Schüller et al. (2016) suggested that there was a negative association between heat stress and conception rate of dairy cows that inseminated by fresh or frozen semen. Schüller et al. (2017) reported lower conception rate in dairy cows when exposed to at the temperature humidity index (THI) above 72 at the day of estrus. Similar trend recoded by Sonmez et al. (2005) who found impaired reproductive parameters of cattle when the temperature humidity index (THI) increased over 72 . Peralta et al. (2005) reported lower pregnancy rate during heat stress in dairy cows due to reduced estrus detection rates. Paula-Lopes et al. (2012) reported that if the uterine temperature increases $0.9^{\circ} \mathrm{F}$ conception rate decline by $6.9 \%$ in the cattle. Sonmez et al. (2005) reported that conception rate was higher in winter season $(71.4,73.3 \%)$ compared with summer season $(48.7,47.9 \%)$ in beef and dairy cows respectively. Cavestany et al. (1985) suggested that ambient temperature above $27^{\circ} \mathrm{C}$ on the day of mating was accompanied with decline of conception rates. Conception rates were $40 \%$ to $60 \%$ during the cold season decreased to $10 \%$ or $20 \%$ during hot summer season. Lopez-Gatius (2003) found lower conception rates in dairy cattle when the cows were exposed to hot months after mating. Shearer and Beede (1990) and Hansen et al. (1992) suggested that heat stress is responsible to re-distribution of the circulating blood flow in the animal body from internal to external, leading to increase reproductive tract temperature, decline nutrient exchange and modification in the volume and content secretions of oviduct and uterine. Paula-Lopes and Hansen (2002) and Soto and Smith (2009) reported that heat stress induces apoptosis in the cells of embryo in cows. Sugiyama et al. (2007) found that there is a detrimental effect of heat stress at the onset of service on oocytes and sperm leading to impair embryo development. Ealy et al. (1995) and Sakatani et al. (2004) recorded that cows exposed to heat stress during pre-implantation embryos suffer from impairment of the total cell number of blastocysts and decline their development. Telford et al. (1990) and De Sousa et al. (1998) reported that the time when the cow embryos at the 4- to 8-cell stage during zygotic genome activation (ZGA), is considered the most sensitive to heat stress. Ealy et al. (1993) suggested that when exposing the cows to heat stress at an early stage, embryo development decrease. Edwards and Hansen (1996) recorded that heat stress induced embryonic death via intermediate with synthesis of protein.Wolfenson et al. (2000) and Hansen (2009) suggested that heat stress causes embryonic death by oxidative cell damage. Wolfensen et al. (1993) and Bilby et al. (2008) reported that heat stress leads to embryonic death by decreasing production of interferon-tau for signaling pregnancy recognition. Vale (2007) and Sunil Kumar et al. (2011) recorded that increase in air ambient temperatures above $20^{\circ} \mathrm{C}$ to $25^{\circ} \mathrm{C}$ causes to raise internal body temperature and inducing heat stress on livestock. Furthermore, Ferreira et al. (2011) and Gendelman and Roth (2012) reported that exposing the cows to heat stress leads to impair oocyte quality. Gendelman et al.(2010) and Silva et al. (2013) found that lower embryo development was observed in dairy cow under heat stress conditions. Oseni et al. (2005) showed that higher pregnancy rate $(32 \%)$ of Holstein cows was during (September-November), but lower $(24 \%)$ pregnancy rate was recorded during (March to May). Amundson et al. (2006) found negative correlation between temperature humidity index (THI) and pregnancy rate of crossbred cows.

\section{Effect of temperature humidity index (THI) on estrus behavior of Egyptian Baladi cows:}

Table (6) showed that the intensity of estrus symptoms was significantly $\left(\begin{array}{ll}P & <0.05\end{array}\right)$ more incidence of cows that calved during the cold months (December, January and February) (THI) (68.1- 70.5) compared to other cows that calved during (November, March and April) (THI) (74.5-76.9) or (May to October) (THI) (80.1-83.9). This result is in agreement with that reported by Collier et al. (2006) who found that heat stress had a negative effect on estrus behavior of dairy cattle. Roelofs et al. (2010) reported that under heat stress conditions more than $80 \%$ of estruses are undetected in cows. LópezGatius et al. (2005) and Sakatani et al. (2012) found that persistency of high environmental temperature leads to reduce the duration and intensity of estrus symptoms in dairy cows. Wolfenson et al. (1997) and Roth et al. (2001) suggested that heat stress leads to reduce heat detection by decreasing steroidogenic capacity of theca and granulosa cells which causes impairment of estradiol concentrations in the blood of cows. Britt et al. (1986), Lyimo et al. (2000) and Lopez et al. (2004) reported that there was a positive association between circulating estradiol concentration and intensity and duration of estrus in dairy cows. Stevenson et al. (1983) reported a positive relation between intensity of estrus and fertility in cattle. Cummins et al. (2012) suggested that there is a relation between peak estrous activity and fertility in Holstein cows. De Rensis and Scaramuzzi (2003) found that heat stress lead to decline LH concentration in blood and development of the dominant follicle on the ovary low LH concentration cause to impair estradiol secretion, which resulted in estrus signs, is poor expression. Nmez et al. (2005) suggested that dairy and beef cows exhibited low estrus behavior during heat stress in the summer season compared to other seasons. Wise et al. (1988) and Badinga et al (1994) reported that during heat stress in summer season 
concentration of plasma estradiol was low in dairy cow. Wilson et al. (1998) indicated that heat stress reduces follicular growth during the preovulatory period, which lead to decline estradiol concentration at pro-estrus period. Orihuela (2000) suggested that estrus-detection was low and intensity of estrus were reduced during heat stress periods in cattle. Nebel et al. (1997) showed that motor activity and other behaviors symptoms of estrus decline and anestrus and silent ovulation increased during heat stress in summer season. White et al. (2002) reported that a mounted behavior recorded high frequent during estrus in cold months compared to in hot months. Pennington et al. (1985) recorded that there was a decline in mounts behavior frequent during the hot season compared to cold season Holstein cows. Schüller et al. (2017) recorded positive relation between mounting behavior at the day of estrus and increasing environmental THI around dairy cows.

Table 6. Effect of temperature humidity index (THI) on estrus behavior of Egyptian Baladi cows

\begin{tabular}{lccc}
\hline \multicolumn{1}{c}{ Estrus symptoms } & \multicolumn{3}{c}{ Heat stress level } \\
\cline { 2 - 4 } & None & $\begin{array}{c}\text { Mild } \\
\text { THI }\end{array}$ & Moderate \\
\cline { 2 - 4 } & & $(74.5-76.9)$ & $(80.1-83.9)$ \\
\hline No. of estrus cases & $98.1-70.5)$ & 4 & 4 \\
Mounting behavior & $(7 / 9) 77.8^{\mathrm{a}}$ & $(2 / 4) 50^{\mathrm{b}}$ & $(1 / 4) 25^{\mathrm{c}}$ \\
Vaginal mucus discharge & $(6 / 9) 66.7^{\mathrm{a}}$ & $(2 / 4) 50^{\mathrm{b}}$ & $(1 / 4) 25^{\mathrm{c}}$ \\
Swelling of vulva & $(4 / 9) 44.4^{\mathrm{a}}$ & $(1 / 4) 25^{\mathrm{b}}$ & - \\
Bellowing & $(6 / 9) 66.7^{\mathrm{a}}$ & $(1 / 4) 25^{\mathrm{b}}$ & $(1 / 4) 25^{\mathrm{b}}$ \\
Standing behavior & $(9 / 9) 100$ & $(4 / 4) 100$ & $(4 / 4) 100$ \\
\hline
\end{tabular}

a, b and c: values within the same row having different superscripts are significantly different at $(\mathrm{P}<0.05)$

Effect of temperature humidity index on progesterone concentration:

Figure (3) and table (7) indicated that progesterone concentration during the estrous cycle in pregnant Baladi cows was significantly $(P<0.05)$ higher under non-heat stress conditions compared with mild and moderate heat stress. However, progesterone concentration during the estrous cycle in non- pregnant Baladi cows was nearly analogical in none and mild heat stress compared to moderate heat stress figure (4). The current result corresponds with those observed by Howell et al. (1994), Burke et al. (2001) and Wolfenson et al. (2002) who found dairy and beef cows that exposed to heat stress lead to inhibition of luteal function and causing decline in progesterone levels in blood plasma. Alnimer et al. (2002) suggested that concentration of progesterone was higher during winter season compared with summer season in dairy cows. Khodaei-Motlagh et al. (2011) reported that heat stress lead to reduce plasma progesterone concentration in dairy cattle, hence cause for abnormal oocyte maturation, implantation miscarriage and ultimately early embryonic mortality. Wolfenson and Roth (2000) found that heat stress affects follicle quality and hormonal patterns in dairy cows. Schüller et al. (2017) suggested that concentration of progesterone $<1 \mathrm{ng} / \mathrm{ml}$ at the day of estrus decline permanently with increasing temperature humidity index THI $\geq 74$ and size of follicle impair $0.1 \mathrm{~mm}$ for each increasing in THI point at the day of estrus. West (2003) reported that concentration of progesterone was impaired when the cows were exposed to heat stress. Torres-Junior et al. (2008) found that progesterone concentration in plasma was altered with changes of environmental temperatures, heat stress causes fluctuation in progesterone metabolism. Rivera et al. (2011) suggested that low progesterone levels during follicular growth lead to decline quality of embryo in cows. Cerri et al. (2011) showed that higher progesterone concentration at pre and post-mating was related with improved fertility.

Table 7. Effect of temperature humidity index on progesterone concentration (ng/ml) $(\mathrm{Mean} \pm \mathrm{SE})$ at estrus, seven, fourteen and twenty-one days post-estrus of Egyptian Baladi cows

\begin{tabular}{|c|c|c|c|c|c|c|}
\hline \multirow{5}{*}{$\begin{array}{l}\text { Days of estrous } \\
\text { cycle }\end{array}$} & \multicolumn{6}{|c|}{ Heat stress level } \\
\hline & \multicolumn{2}{|c|}{ None } & \multicolumn{2}{|c|}{ Mild } & \multicolumn{2}{|c|}{ Moderate } \\
\hline & \multicolumn{6}{|c|}{ THI } \\
\hline & \multicolumn{2}{|c|}{$(68.1-70.5)$} & \multicolumn{2}{|c|}{$(74.5-76.9)$} & \multicolumn{2}{|c|}{$(80.1-83.9)$} \\
\hline & Pregnant & $\begin{array}{c}\text { Non- } \\
\text { pregnant }\end{array}$ & Pregnant & $\begin{array}{c}\text { Non- } \\
\text { pregnant }\end{array}$ & Pregnant & $\begin{array}{c}\text { Non- } \\
\text { pregnant }\end{array}$ \\
\hline $\begin{array}{l}\text { At estrus } \\
\text { Mean } \pm \text { SE } \\
7 \text { day }\end{array}$ & $0.46 \pm 0.0^{\mathrm{a}}$ & $0.20 \pm 0.02$ & $0.26 \pm 0.02^{\mathrm{b}}$ & $0.18 \pm 0.02$ & $0.23 \pm 0.02^{b}$ & $0.17 \pm 0.02$ \\
\hline $\begin{array}{l}\text { Mean } \pm \text { SE } \\
14 \text { day }\end{array}$ & $3.82 \pm 0.16^{\mathrm{a}}$ & $2.71 \pm 0.10$ & $3.01 \pm 0.16^{\mathrm{b}}$ & $2.31 \pm 0.10$ & $2.96 \pm 0.16^{\mathrm{b}}$ & $2.01 \pm 0.10$ \\
\hline $\begin{array}{l}\text { Mean } \pm \text { SE } \\
21 \text { day }\end{array}$ & $4.79 \pm 0.72^{\mathrm{a}}$ & $3.22 \pm 0.42$ & $4.21 \pm 0.72^{\mathrm{b}}$ & $3.11 \pm 0.42$ & $3.21 \pm 0.72^{\mathrm{c}}$ & $2.22 \pm 0.42$ \\
\hline Mean \pm SE & 6. $84 \pm 0.61^{\mathrm{a}}$ & $0.22 \pm 0.02$ & 5. $32 \pm 0.61^{\mathrm{b}}$ & $0.19 \pm 0.02$ & 4. $12 \pm 0.61^{\mathrm{c}}$ & $0.17 \pm 0.02$ \\
\hline
\end{tabular}

$\mathrm{a}, \mathrm{b}$ and $\mathrm{c}$ : values within the same row having different superscripts are significantly different at $(\mathrm{P}<0.05)$ 


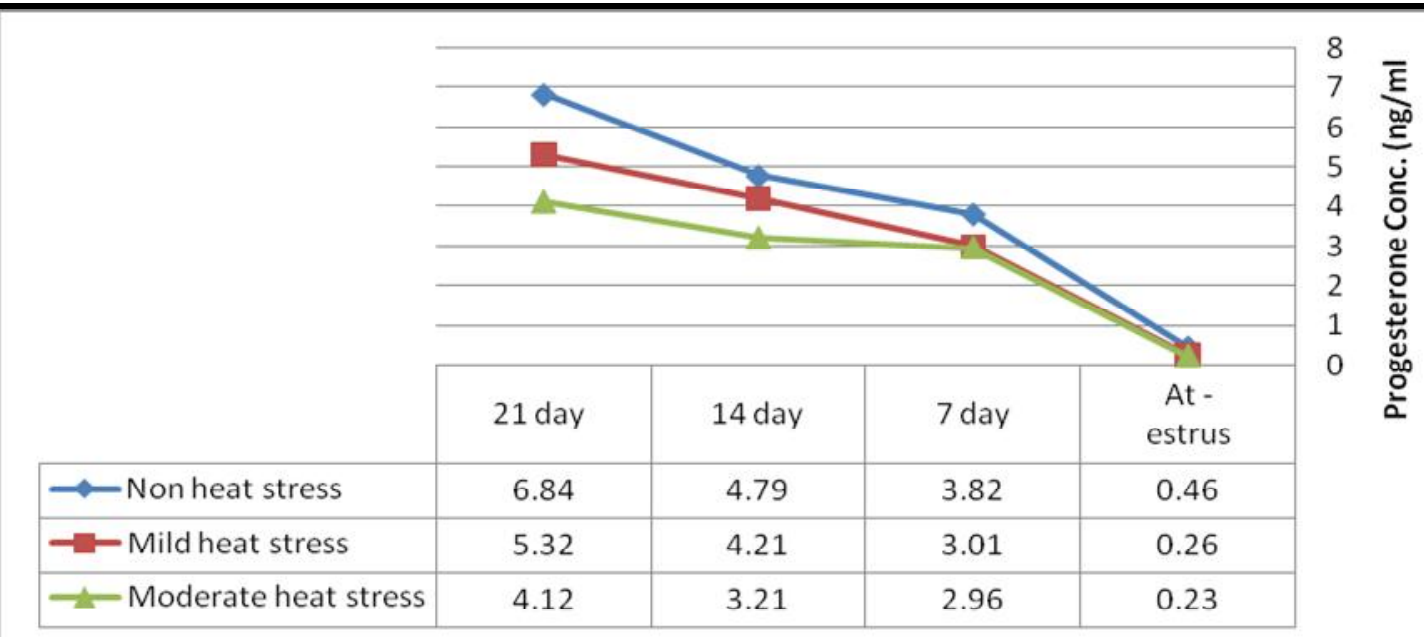

Figure ( 3 ). Progesterone concentration $(\mathrm{ng} / \mathrm{ml}$ ) of pregnant Baladi cattle during non, mild and moderate heat stress

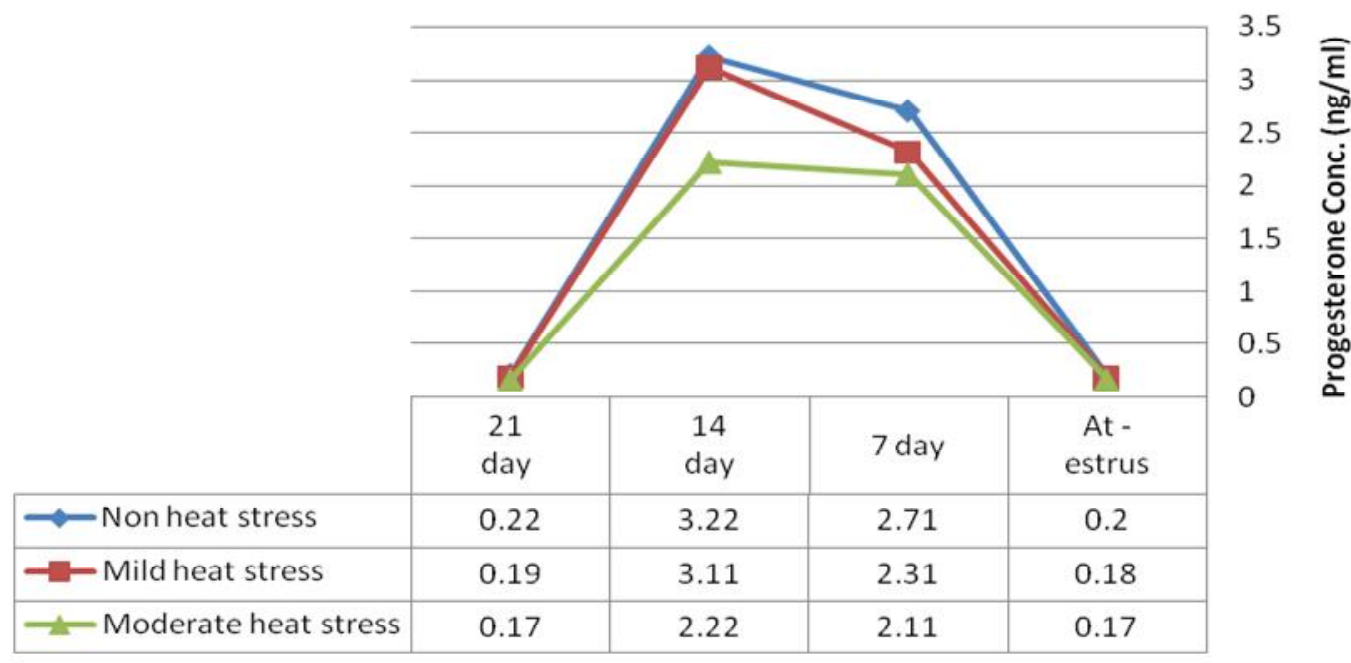

Figure (4 ). Progesterone concentration $(\mathrm{n} / \mathrm{ml})$ of non-pregnant Baladi cattle during non,mild and moderate heat stress

\section{CONCLUSION}

The present results illustrated the detrimental effect of increasing temperature-humidity index level (THI) on ovarian activity and conception rate of Egyptian Baladi cows. Therefore, this study recommends the stockholders of cows in Aswan governorate to arrange the cows calvings during cold months or use some procedures such as sprinkling by water and fan use in order to reduce the harmful effects of increasing THI level on fertility in Egyptian Baladi cows.

\section{REFERENCES}

Alamer, M., 2011.The role of Prolactin in thermoregulation and water balance during heat stress in domestic animals. Asian J. Anim. Vet. Adv., 12: 1153-1169.

Alnimer, M., G. De Rosa, F. Grasso, F. Napolitano, A. Bardi, 2002.Effect of climate on the response to three oestrous synchronisation techniques in lactating dairy cows. Anim. Reprod., Sci., 71: 157-68.

Amundson, J.L., T. L. Mader, R. J. Rasby, and Q. S. $\mathrm{Hu}, 2006$. Environmental effects on pregnancy rate in beef cattle. J. Anim. Sci., 84: 3415-3420.

Arthur, G. H., 1964. Method of rectal examination. Wright's Vet. Obs., 4: 71-80.

Astiz, S. and O. Fargas, 2013. Pregnancy per AI differences between primiparous and multiparous high-yield dairy cows after using double Ovsynch or G6G synchronization protocols Theriogenology, 79: 1065-1070. 
Badinga, L., W. W. Thatcher, C. J. Wilcox, G. Morris, K. Entwistle, D. Wolfenson, 1994.Effect of environmental heat stress on follicular dynamics and plasma concentrations of oestradiol-17 $\alpha$, progesterone and luteinizing hormone in lactating Holstein cows. Theriogenology, 42: 1263-1274.

Bearden, H. J. and J. W. Fuquay, 1992. Applied Animal Reproduction. $3^{\text {rd }}$ ed. Englewood Cliffs: Prentice Hall, pp273-282.

Bilby, T.R., L.H. Baumgard,R. J. Collier, R. B.Zimbelman, and M. L. Rhoads, 2008. Heat stress effects on fertility: Consequences and possible solutions. In the Proceedings of the South Western Nutritional Conference.

Britt, J. H., R. G. Scott, J. D. Armstrong and M. D. Whitacre, 1986.Determinants of estrous behavior in lactating Holstein cows. Journal of Dairy Sci., 69 :2195-2202.

Burke, J. M., D. E., Spiers, F. N. Kojima, G. A. Perry, B. E.Salfen, S. L. Wood, D. J. Patterson, M. F. Smith, M. C. Lucy, W. G. Jackson and E. L. Piper, 2001. Interaction of endophyte-infected fescue and heat stress on ovarian function in the beef heifer. Biol. Reprod., 65:260-268.

Cavestany, D., A.B. El-Whishy, and R.H Foot,1985.Effect of season and high environmental temperature on fertility of Holstein cattle. J. Dairy Sci., 68(6): 1471-1478.

Cerri, R. L. A., R.C. Chebel, F. Rivera,C. D. Narciso, R. A. Oliveira,W.W. Thatcher and J. E. P. Santos, 2011. Concentration of progesterone during the development of the ovulatory follicle: I. Ovarian and embryonic responses. Journal of Dairy Sci., 94: 3342-3351.

Collier, R. J.,G.E. Dahl and M.J. VanBaale, 2006.Major Advances Associated with Environmental Effects on Dairy Cattle. Journal of Dairy Sci., 89(4):1244-1253.

Cummins, S.B., P.Lonergan, A. C. Evans and S. T. Butler, 2012. Genetic merit for fertility traits in Holstein cows: II. Ovarian follicular and corpus luteum dynamics, reproductive hormones, and estrus behavior. Journal of Dairy Sci., 95: 36983710 .

Curtis, A. K., B. Scharf, P.A. Eichen, D.E. piers, 2017. Relationships between ambient conditions, thermal status, and feed intake of cattle during summer heat stress with access to shade. Journal of Thermal Biology, 63:104-111.

De Rensis, F., and R. J.Scaramuzzi, 2003.Heat stress and seasonal effects on reproduction in the dairy cow - areview. Theriogenology, 60:1139-1151.

De Sousa, P. A., A. Caveney, M. E.Westhusin and A. J. Watson 1998. Temporal patterns of embryonic gene expression and their dependence on oogenetic factors. Theriogenology, 49:115-128.

DeRensis, F.,

P. Marconi, T. Capelli, F. Gatti, F. Facciolongo, S . Franzini and R.J. Scaramuzzi, 2002. Fertility in postpartum dairy cows in winter or summer following estrus synchronization and fixed time AI after the induction of an LH surge with GnRH or hCG. Theriogenology, 58: 1675-1687.

DeRensis, F., F. Lopez-Gatius, I. García-Ispierto, G. Morini and R. J. Scaramuzzi,2017. Causes of declining fertility in dairy cows during the warm season. Theriogenology, 91:145-153

Duncan, D. B., 1955. Multiple ranges and multiple F. Test. Biometrics, 11:1-24.

Ealy, A. D., J. L. Howell, V. H. Monterroso, C. F. Arechiga and P. J. 1995. Hansen .Developmental changes in sensitivity of bovine embryos to heat shock and use of antioxidants as thermoprotectants. J Anim. Sci., 73:1401-7.

Ealy, A.D., M. Drost and P. J. Hansen, 1993. Developmental changes in embryonic resistance to adverse effects of maternal heat stress in cows. J. Dairy Sci., 76: 2899-2905.

Edwards, J.L. and Hansen, P.J. 1996. Elevated temperature increases heat shock protein 70 synthesis in bovine two-cell embryos and compromises function of maturing oocytes. Biol. Reprod., 55: 340-346.

Ferreira, R.M., H. Ayres, M.R. Chiaratti, M.L. Ferraz, A.B. Araujo, and C.A. Rodrigues,. 2011. The low fertility of repeat-breeder cows during summer heat stress is related to a low oocyte competence to develop into blastocysts. J Dairy Sci., 94:2383-2392.

Garcia-Ispierto, F., I., F. Lopez-Gatius, G.BechSabat, P. Santolaria, J. L.Yaniz, C. Nogareda, F. De Rensis, and M. Lopez-Bejar, 2007.Climate factors affecting conception rate of high producing dairy cows in northeastern Spain. Theriogenology,67: 1379-1385.

Gendelman, M. and Z. Roth, 2012. Seasonal effect on germinal vesicle-stage bovine oocytes is further expressed by alterations in transcript levels in the developing embryos associated with reduced developmental competence. Biol. Reprod., 86:1-9.

Gendelman, M., A. Aroyo, S. Yavin and Z. Roth, 2010.Seasonal effects on gene expression, cleavage timing, and developmental competence of bovine preimplantation embryos Reproduction, 140:73-82.

Gilad, E., R. Meidan, A. Berman, Y. Graber and D. Wolfenson, 1993.Effect of heat stress on tonic and GnRH-induced gonadotrophin secretion in relation to concentration of oestradiol in plasma of cyclic cows. J. Reprod. Fertil., 99: 315-321.

Hansen, P.J., M. Drost, R. M. Rivera, F. F. PaulaLopes, Y. M. Al-Katanani, C. E. Krininger, C. C. Chase, 2001. Adverse impact of heat stress on embryo production: causes and strategies for mitigation. Theriogenology.55:91-103.

Hansen, P. J., W. W. Thatcher and A. D. Ealy, 1992. Methods for reducing effects of heat stress on pregnancy, in Van Horn, Wilcox CJ (eds): Large Dairy Herd Management. Champaign, IL, American Dairy Sci., Association, pp, 116-125. 
Hansen, P. J., 1994. Causes and possible solutions to the problem of heat stress in reproductive management of dairy cows: Proceedings of the National Reproductive Symposium. Pittsburgh, PA.

Hansen, P. J., 2007. Exploitation of genetic and physiological determinants of embryonic resistance to elevated temperature to improve embryonic survival in dairy cattle during heat stress. Theriogenology,68(1): S242-S249.

Hansen, P.J., 2009. Effects of heat stress on mammalian reproduction. Phil. Trans. R. Soc. B., 364: 3341-3350.

Hansen, P.J. and C. F.Aréchiga,1999. Strategies for managing reproduction in the heat stressed. J. Biol. Sci., 1(1):1-8.

Howell, J. L., J. W. Fuquay and A. E. Smith, 1994. Corpus luteum growth and function in lactating Holstein cows during spring and summer. J Dairy Sci., 77:735-9.

Ju, J.C., 2005. Cellular responses of oocytes and embryos under thermal stress: hints to molecular signaling. Anim. Reprod., 2(2):79-90.

Khodaei-Motlagh, M.M., A.ZareShahneh, R.Masoumi, and D. Fabio, 2011. Alterations in reproductive hormones during heat stress in dairy cattle. Afr. J. Biotechnol., 10(29): 5552-5558.

Kumar, P.R., S. K. Singh, S. D.Kharche, G.Chethan Sharma, B. K.Behera, S. N.Shukla, H. Kumar, S. K. Agarwal, 2014. Anestrus in cattle and buffalo: Indian perspective. Adv. Anim. Vet. Sci., 2 (3): $124-138$.

Lee, C. N., 1993. Environmental stress effects on bovine reproduction. Veterinary Clinics of North America Food Animal Practice, 9: 263-273.

Lewis, G.S., W. W. Thatcher, E. L. Bliss, M. Drost and R. J. Collier, 1984. Effects of heat stress during pregnancy on postpartum reproductive changes in Holstein cows. J. Anim. Sci., 58: 174186.

Lopez, H., L. D. Satter and M. C. Wiltbank, 2004.Relationship between level of milk production and estrous behavior of lactating dairy cows.Animal Reprod. Sci., 81: 209-223.

López-Gatius, F.,P. Santolaria, I. Mundet and J.L. Yániz, 2005.Walking activity at estrus and subsequent fertility in dairy cows Theriogenology, 63:1419-1429.

López-Gatius,F., A. Mirzaei, P. Santolaria, G. BechSàbat, C.Nogareda, I. García-Ispierto and et al. 2008. Factors affecting the response to the specific treatment of several forms of clinical anestrus in high producing dairy cows Theriogenology, 69:1095-1103.

Lopez-GatiusIs, F., 2003.Fertility declining in dairy cattle? A retrospective study in northeastern Spain Theriogenology, 60:pp. 89-99.

Lucy, M.C., 2002. Reproductive loss in farm animals during heat stress. In the Proceeding of 15th Conference on Biometeorology and Aerobiology and the 16th International Congress of Biometeorology, pp: 50-53.
Lyimo, Z. C., M. Nielen, W.Ouweltjes, T. A.Kruip and F. J. Van Eerdenburg, 2000.Relationship among estradiol, cortisol and intensity of estrous behavior in dairy cattle.Theriogenology, 53: 1783-1795.

Mader, T. L., M.S. Davis, and T. Brown-Brandl, 2006. Environmental factors influencing heat stress in feedlot cattle. J. Anim. Sci., 84: 712-719.

Mihm, M., A. Baguisi, M. P. Boland, and J. F. Roche, 1994. Association between the duration of dominance of the ovulatory follicle and pregnancy rate in beef heifers. J. Reprod. Fertil., 102: 123-130.

Morton, J. M., W.P. Tranter, D.G. Mayer and N.N. Jonsson, 2007. Effects of environmental heat on conception rates in lactating dairy cows: critical periods of exposure J Dairy Sci., 90:22712278.

Nebel, R.L., S. M. Jobst, M. B. G.Dransfield, S. M. Pandolfi andT. L.Balley, 1997.Use of radio frequency data communication system, HeatWatch, to describe behavioral estrus in dairy cattle. J. Dairy Sci., 80: (Suppl, 1): 179.

Nmez, M. S., E.Demurcu, T. R. K. Gaffari and G. R.Seyfettin, 2005. Effect of season on some fertility parameters of dairy and beef cows in Elazyuprovince.Turk J Vet. Anim. Sci., 29:821828.

Orihuela, A., 2000. Some factors affecting the behavioural manifestation of oestrus in cattle: A review Appl. Anim. Behav. Sci., 70 :1-16.

Oseni, S., I.Misztal, and S.Tsuruta, 2005. Genetic parameters for pregnancy rate in Holstein cattle under seasonal heat stress. Nig. J. Genet., 19: 4357.

Paula-Lopes, F. F. and P. J. Hansen, 2002. Apoptosis is an adaptive response in bovine preimplantation embryos that facilitates survival after heat shock. BiochemBiophys Res Commun., 295:37-42.

Paula-Lopes, F. F., R. S. Lima, P. H. B. Risolia, J.Ispada, M. E. O. A. Assumpção, and J. A.Visintin, 2012. Heat stress induced alteration in bovine oocytes: Functional and cellular aspects. Anim. Reprod., 9(3):395-403.

Pennington, J.A., J. L. Albright, M. A. Diekman and C. J. Callahan, 1985. Sexual activity of Holstein cows: seasonal effects. J. Dairy Sci., 68: 30233030 .

Peralta, O.A., R.E. Pearson and R.L. Nebel, 2005.Comparison of three estrus detection systems during summer in a large commercial dairy herd. Anim. Reprod.Sci., 87: 59-72

Rivera, F.A.,L.G. D. Mendonça,G. L. Jr,J. E. P. Santos, R. V Perez, M. Amstalden,A. CorreaCalderón and R. C. Chebe, 2011. Reduced progesterone concentration during growth of the first follicular wave affects embryo quality but has no effect on embryo survival post transfer in lactating dairy cows. Reproduction, 141: 333-342.

Rodtian, P., G. King, S. Subrod and P. Pongpiachan, 1996. Oestrous behaviour of Holstein cows 
during cooler and hotter tropical seasons. Anim. Reprod.Sci, $45:$ 47-58.

Roelofs, J., F. López-Gatius, R.H. Hunter, F.J. Van Eerdenburg and C.H. Hanzen, 2010. When is a cow in estrus? Clinical and practical aspects. Theriogenology, 74:327-344.

Roth, Z. and P. J. Hansen, 2004.Involvement of apoptosis in disruption of developmental competence of bovine oocytes by heat shock during maturation. Biol. Reprod., 71:1898-906.

Roth, Z., R. Meidan,R. Braw-Tal and D. Wolfenson, 2000. Immediate and delayed effects of heat stress on follicular development and its association with plasma FSH and inhibin concentration in cows. J Reprod Fertil.,120:8390.

Roth, Z., R. Meweidan, A. Shaham-Albalancy, R. Braw-Tal, D.Wolfenson, 2001. Delayed effect of heat stress on steroid production in medium-size and preovulatory bovine follicles Reproduction, 121: 745-751.

Roy, K.S. and B. S.Prakash,2007. Seasonal variation and circadian rhythmicity of the prolactin profile during the summer months in repeat-breeding Murrah buffalo heifers. Reprod. Fertil. Dev., 19: 596-605.

Sakatani, M., S. Kobayashi and M. Takahashi, 2004. Effects of heat shock on in vitro development and intracellular oxidative state of bovine preimplantation embryos. MolReprod. Dev., $67: 77-82$.

Sakatani,

M., A.Z. Balboula, K. Yamanaka and M. Takahashi, 2012.Effect of summer heat environment on body temperature, estrous cycles and blood antioxidant levels in Japanese Black cow.J Anim. Sci., 83:394-402.

Samal, L., 2013. Heat stress in dairy cows reproductive problems and control measures. International Journal of Livestock Research, 13:14-23.

Sartori, R., R. Sartor-Bergfelt, S. A.Mertens, J. N. Guenther, J. J. Parrish and M. C.Wiltbank, 2002.Fertilization and early embryonic development in heifers and lactating cows in summer and lactating and dry cows inwinter. J Dairy Sci., 85: 2803-2812.

SAS, 2002. User's Guide: Statistics, Version 9.0 Edition. SAS Institute Inc., Cary, NC, USA.

Schüller, L. K., O. Burfeind and W. Heuwieser, 2014.Impact of heat stress on conception rate of dairy cows in the moderate climate considering different temperature-humidity index thresholds, periods relative to breeding, and heat load indices Theriogenology, 81:1050-1057.

Schüller, L.K., I.Michaelis and W. Heuwieser, 2017.Impact of heat stress on estrus expression and follicle size in estrus under field conditions in dairy cows. Theriogenology, 102 (15):48-53.

Schüller, L.K., O.Burfeind and W.Heuwieser, 2016.Effect of short- and long-term heat stress on the conception risk of dairy cows under natural service and artificial insemination breeding programs. J dairy Sci.,99 (4): 2996-3002.

Shearer. J. K. and D. K. Beede, 1990.Heat Stress. Part 2: Effects of high environmental temperature on production, reproduction, and health of dairy cattle. Agri. Practice, 11 (5):6-16.

Silva,C.F., E.S. Sartorelli, A.C. Castilho, R.A. Satrap a, R.Z. Puelker, E.M. Razza and etal. 2013. Effects of heat stress on development, quality and survival of Bosindicus and Bostaurus embryos produced in vitro. Theriogenology, 79:351-357.

Singh, M., Chaudhari, B.K., Singh, J.K., Singh, A.K. and P. K. Maurya, 2013. Effects of thermal load on buffalo reproductive performance during summer season. J. Biol. Sci., 1(1): 1-8.

Sonmez, M., E. Demirci, G.Türk and S.Gür, 2005.Effect of season on some fertility parameters of dairy and beef cows in Elazı $\breve{g}$ province. Turk J Vet Anim. Sci., 29: 821-828.

Soto, P. and L. C. Smith, 2009.BH4 peptide derived from Bcl-xL and Baxinhibitor peptide suppresses apoptotic mitochondrial changes in heat stressed bovine oocytes. MolReprod. Dev., 76:637-646.

Souza, A.H., A.Gumen, E. P. Silva, A. P. Cunha, J. N. Guenther, C. M.Peto, D.Z. Caraviello and M. C.Wiltbank, 2007.Supplementation with estradiol-17 $\beta$ before the last gonadotropinreleasing hormone injection of the ovsynch protocol in lactating dairy cows. J dairy Sci., 90: 4623-4634.

Stevenson, J.S., M. K. Schmidtand E. P. Call, 1983.Estrous intensity and conception rates in Holsteins.J dairy Sci., 66: 275-280.

Sugiyama, S., M. McGowan, N. Phillips, M.Kafi and M. Young, 2007.Effects of increased ambient temperature during IVM and/or IVF on the in vitro development of bovine zygotes. Reprod. Domest. Anim., 7 (42):271-274.

Sunil Kumar, B.V., A. Kumar, and M.Kataria, 2011.Effect of heat stress in tropical livestock and different strategies for its amelioration. J. Stress Physiol. Biochem., 7 (1): 45-54.

Telford, N. A., A. J. Watson and G. A. Schultz, 1990. Transition from maternal to embryonic control in early mammalian development: a comparison of several species. MolReprod. Dev., 26:90-100.

Torres-Júnior, J. R., M. F. Pires, W. F. Sá, M. A. Ferreira, J. H. M. Viana, L. S. A. Camargo, A. A. Ramos, I. M. Folhadella, J. Polisseni, C. Freitas, C. A. A. Clemente, M. F. SáFilho, F. F. PaulaLopes and P. S. Baruselli. (2008). Effect of maternal heat-stress on follicular growth and oocyte competence in Bosindicus cattle. Theriogenology, 69:155-166.

Vale, W.G., 2007. Effects of environment on buffalo reproduction. Italian J. Anim. Sci., 6(2): 130-142.

West, J. W., 2003. Effects of heat-stress on production in dairy cattle.J. dairy Sci., 86: 21312144.

Wheelock, J.B., S.R. Sanders, G. Shwartz, L.L. Hernandez, S.H. Baker, J.W. McFadden, L.J. Odens, R. Burgos, S.R. Hartman, R.M. Johnson, 
B.E. Jones, R.J. Collier, R.P. Rhoads, M.J. VanBaale and L.H. Baumgard. 2006. Effects of heat stress and $\mathrm{rbST}$ on production parameters and glucose homeostasis. J. Dairy Sci., 89. Suppl. (1):290-291. (Abstr).

White, F.J., R. P.Wettemann, M. L.Looper, T. M. Prado and G. L. Morgan, 2002. Seasonal effects on estrous behavior and time of ovulation in nonlactating beef cows. J. Anim. Sci., 80: 3053-3059.

Wilson, S.J., R. S. Marion, J. N. Spain, D. E.Spiers, D. H. Keisler, and M. C. Lucy, 1998. Effects of controlled heat stress on ovarian function of dairy cattle. 1. Lactating cows. J. dairy Sci., 81: 21242131.

Wise, M.E., D. V. Armstrong, J. T. Huber, R. Hunter and F.Wiersma, 1988. Hormonal alterations in the lactating dairy cow in response to thermal stress. $\mathrm{J}$ dairy Sci., 71: 2480-2485.

Wolfenson, D., F. F.Bartol, L. Badinga, C. M. Barros, D. N. Marple, K. Cummings, D. Wolf, M. C. Lucy, T. E. Spencer and W. W. Thatcher, 1993. Secretion of PGF $2 \alpha$ and oxytocin during hyperthermia in cyclic and pregnant heifers. Theriogenology, 39: 1129-1141.

Wolfenson, D., H.Sonego, A. Bloch, A.ShahamAlbalancy, M.Kaim, Y.Folman and R.Meidan, 2002. Seasonal differences in progesterone production by luteinized bovine thecal and granulosa cells. Domest. Anim. Endocrinol., 22:81-90.

Wolfenson, D., W. W. Thatcher, L. Badinga, J. D.Savio, R. Meidan, B. J. Lew, R. Braw-Tal and A. Berman, 1995. Effect of heat stress on follicular development during the estrous cycle in lactating dairy cattle. Biol. Reprod., 52:11061113.

Wolfenson, D., F. F.Bartol, L. Badinga, C. M. Barros, D. N.Marple, K. Cummings, D. Wolfe, M. C. Lucy, T. E. Spencer and W. W. Thatcher, 1993. Secretion of PGF $2 \alpha$ and oxytocin during hyperthermia in cyclic and pregnant heifers. Theriogenology, 39: 1129-1141.

Wolfenson, D., B. J. Lew, W. W. Thatcher, Y. Graber and R.Meidan, 1997. Seasonal and acute heat stress effects on steroid production by dominant in cows. Anim. Reprod. Sci., 47: 9-19.

Wolfenson, D., Z. Roth, and R.Meidan, 2000. Impaired reproduction in heat stressed cattle: basic and applied aspects. Anim. Reprod. Sci., 60-61: 535-547.

Zhandi, M., A. Towhidi, M.H. Nasr-Esfahani, P. Eftekhari-Yazdi and A.Zare-Shahneh, 2009.Unexpected detrimental effect of Insulin like growth factor-1 on bovine oocyte developmental competence under heat stress. J Assist Reprod, Genet., 26:605-611.

\section{تأثير مستوى دليل الحرارة والرطوبة على النشاط المبيضى ومعدل الحمل فى الأبقار البلاية المصرية تحت الظروف المناخية لمحافظة أسوان النئ}

أحمد إسماعيل ضمرانى

قسم الإنتاج الحيوانسي، كلية الزراعة والموارب الطبيعية، جامعة أسوان، مصر

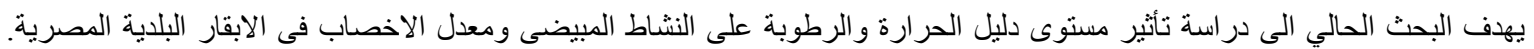

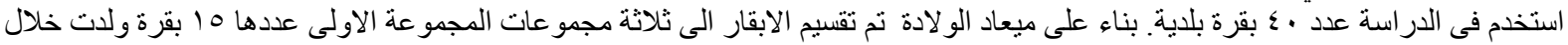

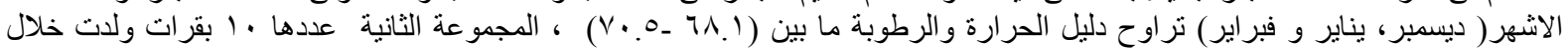

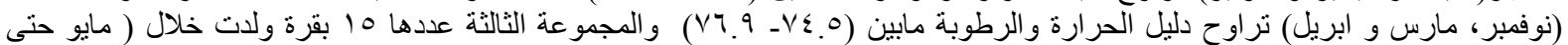

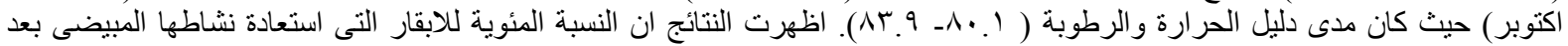

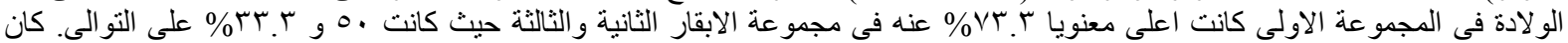

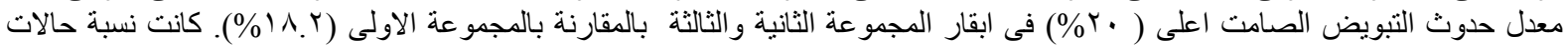

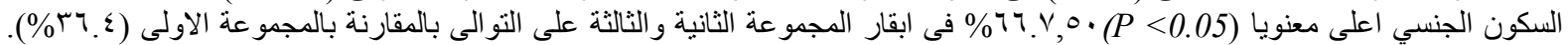

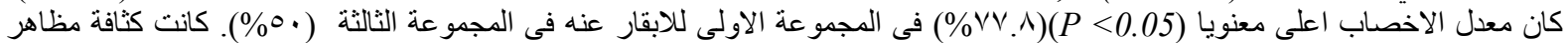

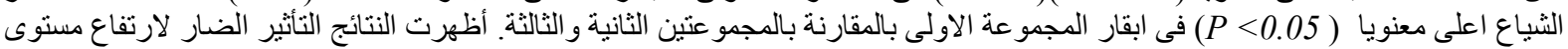

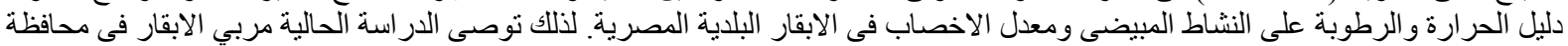

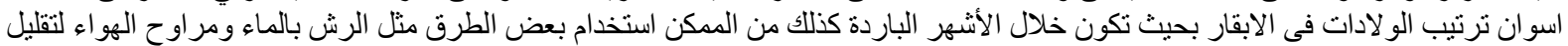

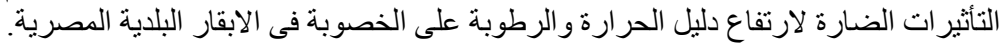

